\title{
Electronic Media Accuracy in Tracking Source of Hadith Research
}

\author{
$1^{\text {st }}$ Masiyan M. Syam ${ }^{1}$ \\ $\left\{\right.$ masiyanmsyam@uinjambi.ac.Id $\left.{ }^{1}\right\}$ \\ Sulthan Thaha Saifuddin State Islamic University of Jambi, Indonesia ${ }^{1}$
}

\begin{abstract}
In era of technology, the use of electronic media cannot be avoided in all aspects of life. In the study of Hadith, the use of this media also cannot be ignored. In some studies, inaccurate data are found in several electronic media. This paper attempts to show the test results on the accuracy of the electronic media in the tracking of initial source of hadith research. This paper is qualitative research by using content analysis to hadith in electronic media presentation of Maktabah Syamilah and Lidwa Pusaka. The results show that some media are accurate, while some others are inaccurate
\end{abstract}

Keywords: Electronic Media; Hadith; Research.

\section{Introduction}

Currently, the position of the Prophet's hadith as the second source after Qur'an is heavily questioned and targeted by criticism. There are criticisms that are useful and there are also criticisms done by cutting compass without going through the knowledge.

When people are confused with the existence of a hadith that doubt its originality and authenticity, antipathy effort is begun. The experts of hadith have a long process. Observations, method discovery, and research rules on hadith begin to be formulated.

The discovery of hadith research rules raises a formula about the validity of hadith. The validity of a hadith is largely determined by validity of sanad and matan [1]. If one of them is invalid, a hadith will not be admitted as a valid hadith. The first step to determine the validity of a hadith is to examine its sanad. There are five rules to determine the validity of a hadith [2]: 1) continuity of sanad (ittis\} $a>l$ al-sanad), 2) credibility of narrators ("ada>lah al$r a>w i>)$, 3) quality of memorizing $(a l-d\} a b t\})$, 4) no irregularity (ghair al-sha>dhdh), 5) no disability (ghair al-'illah).

Criticism of sanad is intended to support the study of hadith with the primary aim to assess the quality of hadith. The five things that need to be a point of emphasis on the research of a sanad will also affect the quality of hadith. While completing the investigation of sanad, one would conclude whether the sanad is valid and good. Then, investigating matan (content) should commence afterward.

With the invention of technology, everything comes in digital mode and this include the hadith. Hadith, nowadays can be found in many digital presentations like CD, e-books, and websites. Consequently, conventional media will gradually be abandoned.

However, in practice, the transfer of this media faces obstacles and various problems. The simplest problem is the information presented by the electronic media does not correspond to 
the information provided by conventional media. However, this digitalization of Hadith comes with several problems to be traced related to: what electronic media used for hadith research? Does this electronic media accurate enough to be used for researching hadith?

This research will focus on e-books in PDF form such as al-Maktabah al-Sha>milah and Lidwa Pusaka as the basis of media transfer in hadith research. This paper is qualitative research by using content analysis to hadith in electronic media presentation of Maktabah Syamilah and Lidwa Pusaka.

\section{Literature Review}

There are several research related to the study hadith in electronic media. Dr. Muh $\{$ ammad Abu $>$ al-Laith al-Khair Aba $>$ di $>$ wrote a book entitled "Takhri $>j$ al-H\{adi $>$ th; Nash'atuh wa Manhajiyyatuh" and was published by Da $>\mathrm{r}$ al-Sha $>$ kir, Malaysia in 2011 [3].

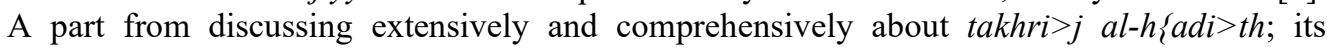
development and methods, he also has a chapter discussing about "Takhri>j al-H $\{$ adi $>$ th with Computer". In this chapter, Abu> al-Laith recommends some softwares that can be used to

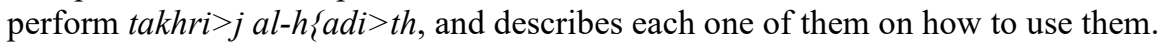

In another chapter, $\mathrm{Abu}>$ al-Laith also explains several hadith books in referent to the description of al-Mu'jam al-Mufahras li Alfa $>z\{a l-H\{a d i>t h$ al-Nabawi $>$ by A. J. Wensinck. He recommends using al-Kutub al-Tis'ah with certain publications and editors in accompanying the practice in al-Mu'jam al-Mufahras. This information is important for closely related to the discussion in this article below.

In addition, there is also research entitled "Review of Hadith Applications (Lidwa Pusaka)" written by Dliya Ul Fikriyyah. This paper was published in the Journal of the Sciences of the Qur'an and Hadith, vol. XVII, no. II, July 2016. The article contains an introduction to the hadith application named Lidwa, its advantages and disadvantages, and the way it operates [4].

\section{Electronic Media Used in Research of Hadith}

\subsection{Portable Document Format (PDF)}

Portable Document Format is one of the most popular and widely used e-book formats such as ePub, HTML, FictionBook, XMDF, BBeb, CBR/CBZ, LIT, Mobipocket/Kindle. This format was created by Adobe System in 1993 for the purposes of digital document exchange. This PDF format is used to represent two-dimensional document that include two dimensional text, letters, imagery, and vector graphics [5].

Generally, PDF file type is the result of the conversation of the file formatted word, excel, power point, and others and transferred into PDF from. In addition, PDF is also a scan of a standard document such as a book, journal or paper, using a scanner tool. It is mostly done on old books including classical books of Islamic studies (tura $>$ th). In other words, PDF is the result of photocopy of digitally formatted book or any document. With the presence of PDF, people are more likely to access and get the books or journals they want, so they do not have to spend the time looking for them in libraries or bookstores, as well as being quite economical. 
In addition, the existence of PDF is very helpful in Islamic studies, considering that the classical books of Islamic studies is quite difficult to find or they are thick enough and complicated for researchers. Similarly, in the study of hadith, almost all of the books are available in PDF format.

Several PDF used in hadith research are al-Mu'jam al-Mufahras li Alfa $>z\}$ al-H\{adi>th al-Nabawi $>$ by A.J. Wensinck, edited by Muh $\{$ ammad Fua $>$ d 'Abd al-Ba $>$ qi $>$. This book is an index book used to trace hadith in primary books of hadith "al-Kutub al-Tis'ah". Dr. Mohamed Abu Laith al-Khair Abadi recommend using al-Kutub al-Tis'ah as below [5]:

(i) $S\{a h\{i>h\{a l-B u k h a>r i>$, edited by Muh $\{\operatorname{ammad} \mathrm{Fu}$ 'a $>$ d 'Abd al-Ba $>\mathrm{qi}>$, published by al-Maktabah al-Isla>miyyah Turkey 1979 , consists of four volumes.

(ii) $S\{a h\{i>h\{$ Muslim, edited by Muh\{ammad Fu'a $>$ d 'Abd al-Ba $>$ qi $>$, published by Da $>$ r Ihya $>$ ' al-Kutub al-'Arabiyyah Cairo 1955, consists of five volumes.

(iii) Sunan $\mathrm{Abi}>\mathrm{Da}>$ wud, edited by 'Izzat 'Ubaid Da' as and 'Adil al-Sayyid, published by $\mathrm{Da}>\mathrm{r}$ al-H $\{$ adi $>$ th Syria 1974 , five volumes.

(iv) Sunan al-Tirmidhi $>$, published by Mus $\{\mathrm{t}\}$ ofa $>$ al-Ba $>$ bi $>$ al-H $\{$ alibi $>$ Cairo 1937 . This book consists of five volumes, each volume is edited by different editor. Volume one and two edited by $\mathrm{Ah}\{\mathrm{mad}$ Sha $>$ kir, volume three is edited by Muh\{ammad Fu' $>$ d 'Abd al-Ba>qi>, and volume four and five are edited by Ibra $>$ hi $>$ m 'At $\}$ wah.

(v) Sunan al-Nasa> ' $i>$, written with explanation ( $h\{a>$ shiyah) by al-Suyu $>t\}$ i $>$ entitled "Zahr al-Rabi" and with $h\{a>$ shiyah by al-Sindi. This book is printed for four volumes by publisher "al-Maktabah al-Tijariyah al-Kubra" Cairo 1348H.

(vi) Sunan Ibn Ma $>$ jah, edited by Muh $\{\mathrm{ammad} F u$ 'a $>$ d 'Abd al-Ba $>\mathrm{qi}>$, published by Da>r Ihya >' al-Kutub al-'Arabiyyah Cairo 1952, consists of two volumes.

(vii) Sunan al-Darimi $>$, edited by Muh $\{\operatorname{ammad}$ Fawaz $\mathrm{Ah}\{\mathrm{mad}$ Zamruli and Kha $>$ lid alSaba' al-"Alami>, published by Da>r al-Rayyan Cairo, the first printed in 1987.

(viii) Muwat $\}$ t $\}$ ' $M a>l i k$, edited by Muh\{ammad Fu'a $>$ d 'Abd al-Ba $>\mathrm{qi}>$, published by Da $>r$ Ihya $>$ ' al-Kutub al-'Arabiyyah Cairo 1951.

(ix) Musnad Ah\{mad, published by Maymu>nah Publisher Egypt 1313H, in six volumes.

The ninth hadith books are the books that recommended in accordance to the study of alMu'jam al-Mufahras li Alfa $>z$ al-H\{adi $>$ th al-Nabawi $>$. Therefore, they are strongly recommended for researchers when tracing hadith.

Other hadith kitab come in PDF format are Rija $>l$ al-H\{adi>th such as Tahdhi $>b$ alKama $>l$ fi $>$ Asma $>$ ' al-Rija $>l$ by Yu $>$ suf al-Mizzi>, Mi $>z a>n$ al-I'tida $>l f i>N a q d$ al-Rija $>l$ by al-Dhahabi $>$, Tahdhi $>b$ al-Tahdhi $>b$ by al-'Asqala $>$ ni $>$, and others.

\subsection{Programs of Hadith}

In this digital era, the use of technology is inevitable. Technology sophistication proved to be very helpful in human life. Not to forget in the academic world, the use of technology is very helpful and facilitate academics in conducting research, including research of hadith. There are several programs that could be used in the study of hadith, and one of them is alMaktabah al-Sha>milah and Lidwa.

Al-Maktabah al-Sha $>$ milah is a computer program containing hundreds of thousands of Arabic books. This program was initiated by al-Maktab al-Ta'a>wuni>li al-Da'wah, Raud \{ah, Saudi Arabia. In the official website www.shamela.ws explained that this program is free dedicated to help students or researchers who need many books. 
Al-Maktabah al-Sha>milah was first released on April 2005 and continues to grow until now with the addition of various features in it. This program contains hundreds of thousands of books from various disciplines of different authors. These books can be downloaded for free from official website. The latest version of al-Maktabah al-Sha>milah is called version 3.64 .

In addition to al-Maktabah al-Sha>milah, program which is also widely used in research of hadith especially in Indonesia is "Hadis Sembilan Imam" (Hadith of Nine Imam). This is a program of hadith studies released by an institution called "Lidwa Pusaka", therefore this program is better known as "Lidwa", not "Hadis Sembilan Imam". Lidwa Pusaka is an abbreviation of Institute of Science and Da'wah and Publication of Religious Facilities (Lembaga Ilmu dan Dakwah serta Publikasi Sarana Keagamaan). Lidwa Pusaka is an institution engaged in the development and publication of Islamic knowledge and da'wah (mission). The institute was founded by scholars graduated from the Middle East, the Islamic and Arab Institute of Sciences (LIPIA) Jakarta and several other universities.

Lidwa Pusaka provides encyclopedia of nine hadith books in two versions: online and offline. Online version can be accessed directly from official website www.lidwa.com. Offline version can be purchased for 389.000 IDR through its official website. This program contains more than 62.000 hadiths from al-Kutub al-Tis'ah; $S\{a h\{i>h$ al-Bukha>ri>, $S\{a h\{i>h\{$ Muslim, Sunan Abi> Da>wud, Sunan Tirmidhi>, Sunan al-Nasa $>$ ' $>>$, Sunan Ibn Ma $>$ jah, Sunan al-Da>rimi $>$, Muwat $t_{\}} a^{\prime}$ Ma>lik and Musnad Ah\}mad. This program is also completed with Bahasa as translation of the hadith and short explanation about the quality and the narrators.

\section{Media Accuracy of The Hadith Studies}

\subsection{The First Hadith}

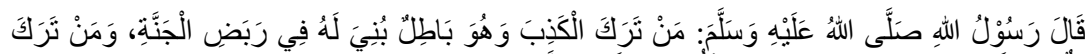

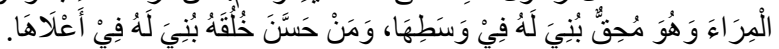

The keyword used in tracing the source of thIS hadith is the word "حسن", it is found in alMu'jam al-Mufahras volume 1 page 466 with the following information [6]:

$$
\text { . . . . . ومن حسن خُلقه . ... . ت برّ 58، د أدب 7، جهـ مقدمة } 7 \text {. . }
$$

Based on al-Mu'jam information above, the hadith is located in several books such as:

(i) Sunan al-Tirmidhi>, volume 4 page 358, kita>b al-birr wa al-s\{ilah, chapter 58 number 1993 [7].

(ii) Sunan $A b i>D a>w u d$, volume 5 page 98, kita $>b$ al-adab, chapter 8 number 4800 [8].

(iii) Sunan Ibn Ma>jah, volume 1 page 19, at muqaddimah, chapter 7 number 51 [9].

After locating the hadith as informed above, this research found inaccurate information occurs between al-Mu'jam and Sunan Abi>Da>wud. As indicated above al-Mu'jam notes that the above mentioned hadith is located in chapter 7, whereas in Sunan Abi>Da>wud it is found in chapter 8 .

This research also investigate the same search of the hadith above in al-Maktabah alSha>milah, using حسن خلقه as keyword, the hadith could be found in Sunan al-Tirmidhi>, Sunan Abi $>D a>w u d$, and Sunan Ibn Ma>jah. The result found in al-Maktabah al-Sha>milah 
match what is found in the PDF, except for Sunan Abi>Da>wud, the hadith is located in volume 7 page 179. The difference is only in volume and page number, not in chapter or hadith number, because the reference used by al-Maktabah al-Sha>milah is different from PDF version used in this research. al-Maktabah al-Sha>milah uses Sunan Abi> Da>wud published by Da>r al-Risa>lah al-'Alamiyyah, 2009, edited by Shu'aib al-Arnaut\}.

The search of hadith above in Lidwa, there are several mismatched in term of numbering of hadith. For example, in Sunan al-Tirmidhi> it is written number 1916, Sunan Abi> $D a>w u d$ number 4167, and Sunan Ibn Ma>jah number 50. This numbering is different from that of written both in PDF and al-Maktabah al-Sha>milah. In addition, in Lidwa there is no information about the chapter name or the chapter number.

\subsection{The Second Hadith}

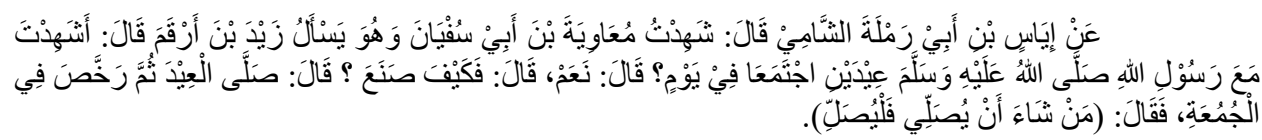

The keyword used to trace the source of this hadith is the word "رخص", it is found in alMu'jam al-Mufahras volume 2 page 241 with the following information [10]:

$$
\text { صلى العيد ثم رخص في الجمعة . . . . د صلاة 211، جه إقامة 166، دى صلاة 225، حم 4، } 372 .
$$

Based on al-Mu'jam information above, I found the hadith in:

(i) Sunan $A b i>D a>w u d$, volume 1 page 451, kita $>b$ al-s\}ala $>h$, chapter 217 number 1070 [11].

(ii) Sunan Ibn Ma>jah, volume 1 page 415, kita $>b$ iqa $>$ mah al-s\}ala $>h$ wa al-sunnah, chapter 166 number 1310 [9].

(iii) Sunan al-Da>rimi $>$, volume 1 page 459, kita $>b$ al-s\}ala $>h$, chapter 225 number 1612 [12].

(iv) Musnad Ah\{mad, volume 4 page 372 [13].

After examine the location of hadith based on the above information, inaccuracy is found between al-Mu'jam information and Sunan Abi> Da>wud. Al-Mu'jam indicates the hadith is located in chapter 211, whereas in Sunan Abi>Da>wud, it is found in chapter 217.

The search of the hadith in al-Maktabah al-Sha>milah using the keyword indicated that this hadith is located in Sunan Abi>Da>wud, Sunan Ibn Ma>jah, Sunan $a l-D a>$ rimi $>$, and Musnad Ah\{mad. However, in Sunan Abi>Da>wud, there are differences on both the volume number and the page number. The same thing happened to Sunan al$D a>$ rimi $>$, with differencies found in pages, chapter numbers, and hadith numbers. In Sunan al-Da $>$ rimi $>$ (al-Maktabah al-Sha>milah), also indicates that hadith is found at volume 1 page 399, kita $>$ b al-s\}ala $>h$, chapter 9 number 1758 .

Different format of the e-book version of Hadith book influenced significantly to the differences in coding for the source Hadith book. For example, al-Maktabah al-Sha>milah provide Sunan al-Da $>$ rimi $>$ from $\mathrm{Da}>\mathrm{r}$ al-Basha $>$ 'ir Beirut in 2013 that edited by Nabi $>1$ Hashi $>$ m al-Ghimari $>$. For Musnad Ah\{mad, the differenccies occurs in volume 32 page 68 which published by al-Risa>lah, Beirut in 2001 and edited by Shu'aib al-Arnaut\}, 'Adil Murshid and others.

Inaccuracy also found in Lidwa related to different numbering of Hadith that stated either in al-Maktabah al-Sha>milah or PDF format. For example Lidwa mentioned the above mentioned hadith located in Sunan Abi> Da>wud with written number 904, Sunan Ibn 
Ma>jah number 1300, Sunan al-Da>rimi> number 1561, and Musnad Ah\{mad number 18513. These numbering are different from that of written in PDF and al-Maktabah alSha $>$ milah.

\subsection{The Third Hadith}

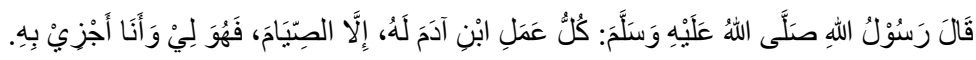

The keyword used for tracing the source of that hadith is the word "صام", it is found in alMu'jam al-Mufahras volume 3 page 460 with the following information [14]:

$$
\begin{aligned}
& \text { كل عمل ابن آدم له إلا الصيام } \\
& \text { 163، ن صيام 42، دي صوم 50، 50، ط صيام } 58 .
\end{aligned}
$$

Based on al-Mu'jam information above, the hadith located in:

(i) Musnad Ah\{mad, volume 2 page 273 and 281 [15].

(ii) $S\{a h\{i>h\{$ Muslim, volume 2 page 806 and 807, kita $>b$ al-s\}iya $>m$, number 161 and $163[16]$.

(iii) Sunan al-Nasa $>$ ' $i>$, volume 4 page 163, kita $>b$ al-s\} iya $>m$, chapter 42 number 2216 [17].

(iv) Sunan $a l-D a>r i m i>$, volume 2 page 40, kita $>b$ al-s\}aum, chapter 50 number 1770 [18].

(v) Muwat\}t\} $a^{\prime}$ Ma $>$ lik, volume 1 page 310, kita $>$ b al-s\}iya $>m$, number 58 [19].

All information contained in al-Mu'jam fits perfectly with what is contained in the books of hadith sources above. Meanwhile, in al-Maktabah al-Sha>milah difference location occurs due to different format used. The differences are: a) At Musnad Ahmad, published by alRisalah, Beirut in 2001 and edited by Shu'aib al-Arnaut\}, 'Adil Murshid and others, the hadith located in volume 7 page 411 and 476; b) Sunan al-Da $>$ rimi $>$ published by Da $>$ r al-Mughni $>$ Saudi Arabia in 2000 and edited by Husein Salim Asad al-Darani, the hadith is located in volume 2 page 1110, number 1811; c) Muwat\}t\}a' printed by Muassasah Zayd bin Sult\}an $\mathrm{Abu}>$ Dhabi in 2004 and edited by Muh $\{\operatorname{ammad}$ Mus $\} \mathrm{t}\}$ ofa $>$ al-A'z $\}$ ami $>$, the hadith is located in volume 3 page $445-446$.

Meanwhile, several differences occur in Lidwa related to different numbering of Hadith in several kitab such as in Musnad Ah\{mad with the number of 7368, in $S\{a h\{i>h\{$ Muslim with the number of 1944, in Sunan al-Nasa $>$ ' $i>$ with the number of 2186, Sunan al-Da>rimi $>$ with the number of 1705, and Muwat\}t\} $a^{\prime}$ Ma>lik with the number of 603 .

\subsection{The Fourth Hadith}

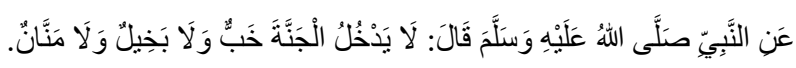

The keyword used in tracing the source of this hadith is the word "خبّ", it is found in alMu'jam al-Mufahras volume 2 page 1 with the following information [10]:

$$
\text { لا يدخل ...... الجنة خَبٌّ ...... حم 1، 4، 7، ت برّ } 41
$$

Based on al-Mu'jam information above, the hadith is presented in:

(i) Musnad Ah\{mad, volume 1 page 4 and 7 [20]. 
(ii) Sunan al-Tirmidhi>, volume 4 page 343, kita $>$ b al-birr wa al-s\{ilah, chapter 41 number 1963 [7].

All information contained in al-Mu'jam al-Mufahras fits perfectly with what is contained in the hadith books above. However, the difference occurs to al-Maktabah al-Sha>milah that located in Musnad Ah\{mad, the hadith available in volume 1 page 181, number of hadith 31 . In Lidwa the hadith available in Musnad Ah\{mad numbered 32, and Sunan al-Tirmidhi> numbered 1886.

\subsection{The Fifth Hadith}

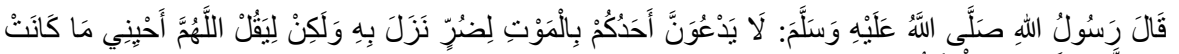

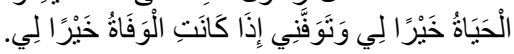

The keyword used in tracing the source of this hadith is the word "موت", it is found in alMu'jam al-Mufahras volume 6 page 291 with the following information [21]:

$$
\text { لا يدعونّ (أحدكم)، تدعوا بالموت }
$$

Based on al-Mu'jam information above, the hadith available in:

1. Sunan $A b i>D a>w u d$, volume 3 page 314 , kita $>b$ al-jana $>$ 'iz, chapter 13 number 3108 [22].

2. Sunan al-Nasa $>$ ' $i>$, volume 4 page 3 , kita $>b$ al-jana $>$ 'iz, chapter 1 number 1820 [17].

Incompatibility between the information in al-Mu'jam and in Sunan Abi> Da>wud occurred related to the location of hadith. In al-Mu'jam indicates that hadith in chapter 9, whereas in Sunan Abi>Da>wud, it is found in chapter 13. Likewise in al-Maktabah alSha $>$ milah, the Hadith is found in Sunan Abi $>D a>$ wud in volume 5 page 24. This differences is result from different prints edition used in both al-Maktabah al-Sha>milah and the (PDF) program.

\section{Conclusion}

Based on the above description, this paper concludes that the use of electronic media in the hadith studies cannot be ignored or avoided. We found various electronic media presentation available to use for. Among the many electronic media used in hadith research is PDF, which is a digital form of the conventional book. The use of PDF is the same as the ordinary books, which distinguish only the medium but the content remains the same. Therefore, research using PDF books is as accurate as using the conventional book.

Unlike the PDF, al-Maktabah al-Sha>milah has a lower accuracy. After comparing the PDF and al-Maktabah al-Sha>milah, this study found that al-Maktabah al-Sha>milah used different reference prints edition and / or different editors, resulting in a disagreement with the recommended books according to al-Mu'jam al-Mufahras li Alfa $>z$ \} al-H\}adi $>$ th al-Nabawi $>$.

Lidwa Pusaka is less accurate than that of two resources mentioned earlier. There are significant differences found in comparison to two other sources. In addition, Lidwa did not explain further important information like name of the book, chapter number, publisher name, publication year and editor (muhaqqiq). Therefore, for this research it is not recommended to use Lidwa for hadith research. 
Further research should be conducted related to these sources, especially related to different edition that might cause differences in number of hadith, volume and also pages. Thus, accuracy of electronic media presentation for hadith studies needs detail and careful transformation so that the content is as accurate as conventional book.

\section{References}

[1] Rais M, Aryani F and Ahmar A S 2018 The influence of the inquiry learning model and learning style on the drawing technique of students $2064-8$

[2] Ahmar A S, Rahman A, Ansari S. Ahmar and Abdul Rahman 2017 Development of teaching material using an Android Glob. J. Eng. Educ. $1972-6$

[3] Sriadhi S, Rahim R and Ahmar A S 2018 RC4 Algorithm Visualization for Cryptography Education J. Phys. Conf. Ser. 102812057

[4] Kartikadarma E, Listyorini T and Rahim R 2018 An Android mobile RC4 simulation for education World Trans. Eng. Technol. Educ. 16 75-9

[5] Napitupulu D, Rahim R, Abdullah D, Setiawan M I, Abdillah L A, Ahmar A S, Simarmata J, Hidayat R, Nurdiyanto H and Pranolo A 2018 Analysis of Student Satisfaction Toward Quality of Service Facility J. Phys. Conf. Ser. 95412019

[6] Adiyarta K, Napitupulu D, Rahim R, Abdullah D and Setiawan M 2018 Analysis of e-learning implementation readiness based on integrated elr model J. Phys. Conf. Ser. 100712041

[7] Rossanty Y, Hasibuan D, Napitupulu J, Nasution M D T P and Rahim R 2018 Composite performance index as decision support method for multi case problem Int. J. Eng. Technol. 7 33-6

[8] Nasrudin N, Agustina I, Akrim A, Ahmar A S and Rahim R 2018 Multimedia educational game approach for psychological conditional Int. J. Eng. Technol. 7 78-81

[9] Rahim R, Zufria I, Kurniasih N, Simargolang M Y M Y, Hasibuan A, Sutiksno D U, Nanuru R F, Anamofa J N, Ahmar A S and Achmad Daengs G S 2018 C4 . 5 Classification Data Mining for Inventory Control Int. J. Eng. Technol. 7 68-72

[10] Mesran M, Syahrizal M, Suginam S, Kurniasih N, Gs A D, Achmad Daengs G S, Ahmar A S and Rahim R 2018 Expert System for Disease Risk Based on Lifestyle with Fuzzy Mamdani Int. J. Eng. Technol. 7 88-91

[11] Ding D, Cooper R A, Pasquina P F and Fici-Pasquina L 2011 Sensor technology for smart homes Maturitas 69 131-6

[12] Ansari A N, Navada A, Agarwal S, Patil S and Sonkamble B A 2011 Automation of attendance system using RFID, biometrics, GSM modem with .Net framework 2011 International Conference on Multimedia Technology, ICMT 2011 pp 2976-9

[13] Suyono J, Sukoco A, Setiawan M I, Suhermin S and Rahim R 2017 Impact of GDP Information Technology in Developing of Regional Central Business (Case 50 Airports IT City Development in Indonesia) Journal of Physics: Conference Series vol 930

[14] Florence S, Kumari C S and Priyadharshini L L 2018 Smart health monitoring system based on internet of things with big data analytics and wireless networks Int. J. Eng. Technol. 7 109-11

[15] Napitupulu D, Syafrullah M, Rahim R, Amar A and Sucahyo Y 2018 Content validity of critical success factors for e-Government implementation in Indonesia IOP Conf. Ser. Mater. Sci. Eng. 35212058

[16] Adiyarta K, Napitupulu D, Nurdianto H, Rahim R and Ahmar A 2018 User acceptance of EGovernment Services Based on TRAM model IOP Conf. Ser. Mater. Sci. Eng. 35212057

[17] Siti Zuraida Abdul Manaf Ahmad Syukri Mohamad Zaid, Rosseni Din, Analisa Hamdan, Nor Syazwani Mat Salleh, Intan Farahana Kamsin, Aidah Abdul Karim, Maimun Aqsya Lubis 2015 Aplikasi Mudah Alih Panduan Solat dan Penggunaannya Ulum Islam. J.

[18] Sarkissian A 2012 Religion and Civic Engagement in Muslim Countries J. Sci. Study Relig. 
[19] Al-Krenawi A and Graham J R 2000 Islamic theology and prayer: Relevance for social work practice Int. Soc. Work

[20] El-Hoseiny M H and Shaban E 2009 Muslim prayer actions recognition 2009 International Conference on Computer and Electrical Engineering, ICCEE 2009

[21] Napitupulu D, Syafrullah M, Rahim R, Abdullah D and Setiawan M 2018 Analysis of user readiness toward ICT usage at small medium enterprise in south tangerang J. Phys. Conf. Ser. 1007 12042

[22] Suryanto T, Rahim R and Ahmar A S 2018 Employee Recruitment Fraud Prevention with the Implementation of Decision Support System J. Phys. Conf. Ser. 102812055

[23] Rahim R, Supiyandi S, Siahaan A P U, Listyorini T, Utomo A P, Triyanto W A, Irawan Y, Aisyah S, Khairani M, Sundari S and Khairunnisa K 2018 TOPSIS Method Application for Decision Support System in Internal Control for Selecting Best Employees J. Phys. Conf. Ser. 102812052

[24] Kurniasih N, Kurniasih N, Abdillah L A, Sudarsana I K, Yogantara I W L, Astawa I N T, Nanuru R F, Miagina A, Sabarua J O, Jamil M, Tandisalla J, Duan E, Rupilele F G J, Utama M D, Laisila M, Ahmar A S and Rahim R 2018 Prototype Application Hate Speech Detection Website Using String Matching and Searching Algorithm Int. J. Eng. Technol. $762-4$

[25] Rahim R, Simarmata J, Purba A, Prayogi M A, Sapta A, Krianto O, Sembiring M A, Ramadhani R and Suryanti A R 2018 Internet based remote desktop using INDY and socket component Int. J. Eng. Technol. 7 44-7

[26] Setiabudi D H and Tjahyana L J 2013 Mobile learning application based on hybrid mobile application technology running on Android smartphone and Blackberry Int. Conf. ICT Smart Soc. 1-5 [27] Listyorini $\mathrm{T}$ and Rahim R 2018 A prototype fire detection implemented using the Internet of Things and fuzzy logic World Trans. Eng. Technol. Educ. $1642-6$

[28] Rahim R, Afriliansyah T, Winata H, Nofriansyah D, Ratnadewi and Aryza S 2018 Research of Face Recognition with Fisher Linear Discriminant IOP Conf. Ser. Mater. Sci. Eng. 30012037

[29] Upton D 2007 Codeigniter for Rapid Php Application Development

[30] Setiawan A, Endrawan D, Fathoni R and P S B 2011 Rapid Application Development Sist. Inf. [31] Jannach D, Kreutler G, Systems I R and Development M W A 2007 Rapid development of knowledge-based conversational recommender applications with advisor suite J. Web Eng.

[32] Daud N M N, Bakar N A A A and Rusli H M 2010 Implementing Rapid Application Development (RAD) methodology in developing practical training application system Proceedings 2010 International Symposium on Information Technology - System Development and Application and Knowledge Society, ITSim'10

[33] Improvement P and Development R A 1998 A quality software process for rapid application development Softw. Qual. J. 